\title{
Antiplatelet Effects of Fenflumizole, a New Anti-Inflammatory Drug, in Dogs
}

\author{
Hiroyuki NABATA, Masako UCHINO**, Akira OKAZAKI* \\ and Kazushige SAKAI**
}

Department of Pharmacology and *Drug Metabolism, Research Laboratories.

Chugai Pharmaceutical Co., L.td., Takada, Toshima-ku, Tokyo 171, Japan

Accepted March 7, 1987

\begin{abstract}
Fenflumizole (2-(2,4-difluorophenyl)-4,5-bis(4-methoxyphenyl) imidazole) was given to dogs in a single oral dose of 3 or $10 \mathrm{mg} / \mathrm{kg}$. The plasma concentrations of fenflumizole and the two metabolites (mono- and di-demethyl forms) attained to the peak level 1-2 hr after dosing of fenflumizole, returning to near the predose levels $8 \mathrm{hr}$ after the dosing. Fenflumizole $(10 \mathrm{mg} / \mathrm{kg})$ given orally significantly inhibited collagen- and ADP-induced platelet aggregations ex vivo over $4 \mathrm{hr}$ after the dosing. Fenflumizole effectively inhibited in vitro collagen-induced platelet aggregation, but failed to prevent ADP-induced aggregation. The mono-demethyl form of fenflumizole inhibited in vitro ADP- and collagen-induced aggregations, but the di-demethyl form was ineffective in inhibiting them.
\end{abstract}

Fenflumizole, 2-(2,4-difluorophenyl) -4,5bis(4-methoxyphenyl)imidazole, is one member of a novel series of imidazole derivatives with anti-inflammatory, analgesic and anti-pyretic properties (1). Corell et al. (2) reported that fenflumizole also possesses a potent cyclooxygenase inhibitory activity Non-steroidal anti-inflammatory agents are generally limited in their clinical application because of the high incidence of gastrointestinal ulcerations associated with the use of these drugs (3). However, fenflumizole seems to have retained therapeutic activities but reduced side effects, compared to other non-steroidal anti-inflammatory drugs, particularly on the gastro-intestinal tract ( 1 . 4). Recently, its anti-platelet effects against various aggregating agents have been noted in animals (2, 4, 5) and humans (2, 6, 7). The present study was undertaken to evaluate further the anti-platelet effect of fenflumizole against collagen and ADP, together with its pharmacokinetics, in dogs.

Male beagle dogs weighing 9.5 to $12.0 \mathrm{~kg}$ were used.

** To whom correspondence should be addressed.
In vitro studies: Three animals were anesthetized i.v. with $30 \mathrm{mg} / \mathrm{kg}$ of $\mathrm{Na}$ thiobarbitone. The blood was withdrawn from the cannulated left carotid artery into glass syringes containing $3.8 \%$ sodium citrate solution (citrate: blood $=1: 9$ ). Platelet-rich plasma (PRP) was prepared by centrifuging the blood for $8 \mathrm{~min}$ at $1100 \mathrm{rpm}(190 \times \mathrm{g})$. After PRP was separated, the remaining aliquot was centrifuged for $15 \mathrm{~min}$ at 3000 $\mathrm{rpm}(1300 \times \mathrm{g})$, and platelet-poor plasma (PPP) was obtained. A platelet counter (Model ZB1, Coulter Electronics) was used to adjust the number of platelets in PRP to a constant value $\left(3 \times 10^{5}\right.$ platelets $\left./ \mu 1\right)$ in each experiment with homologous PPP. Each sample was prewarmed for 5 min at $37^{\circ} \mathrm{C}$ and stirred at $1100 \mathrm{rpm}$ before addition of drugs. Then, $20 \mu \mathrm{l}$ of drug solution or vehicle was added to each sample, and 2 min later. 20 «l of aggregating agents were also added. The final concentrations of aggregating agents were $30 \mu \mathrm{g} / \mathrm{ml}$ collagen and $7.5 \mu \mathrm{M}$ ADP, concentrations which induced about $75 \%$ of the maximal aggregation. The aggregation curve was monitored by means of a blood platelet aggregometer (NKK platelet 
aggregation tracer, model PAT-4M, SSR Engineering Co.). Inhibition of platelet aggregation was assessed by comparing maximal optical transmission changes of the drugtreated PRP sample with the vehicle-treated PRP sample and expressed as percentage changes.

Ex vivo studies: Five animals were given orally fenflumizole ( 3 or $10 \mathrm{mg} / \mathrm{kg}$ as tablets containing 5 or $50 \mathrm{mg}$ of fenflumizole) or placebo (lactate) at random once a week. approximately $1 \mathrm{hr}$ after the intake of food (9 a.m.). Venous blood samples $(5.0 \mathrm{ml}$ ) were withdrawn from the cephalic vein before and 1, 2, 3. 4, 6 and $8 \mathrm{hr}$ after the oral dosing. Platelet aggregation tests were performed according to the same procedure as described in the in vitro studies. Inhibition of platelet aggregation was assessed by comparing maximal optical transmission changes of the pre-dosing PRP sample with the post-dosing PRP sample and expressed as percentage changes.

In the same preparation, the pharmacokine tic study was made. To avoid photodecomposition of fenflumizole, blood samples were carefuliy protected from light. Blood was centrifuged for $10 \mathrm{~min}$ at $3000 \mathrm{rpm}$ with a Hitachi Refrigerated Centrifuge (O5PR-22). Plasma was separated and frozen at $-80^{\circ} \mathrm{C}$ until assayed (within one week). The plasma concentrations of fenflumizole and the two metabolites (Fig. 1) were determined according to a small modification of the method of Midskov (8).

The drugs used were: 2-(2,4-difluorophenyl) -4,5-bis (4-methoxyphenyl)imidazole. fenflumizole, and mono- and di-demethyl fenflumizole (all from Dumex, Denmark; see Fig. 1): collagen (Hormonchemie, München GMBH) : and ADP (adenosine 5'-diphosphate from equine muscle, Sigma). Fenflumizole and it's metabolites were dissolved in $2 \%$ dimethyl sulfoxide solution and diluted with $0.9 \%$ saline solution. Collagen and ADP were dissolved in and diluted with $0.9 \%$ saline solution.

The data in the text are expressed as values of the mean $\pm S$.E. Significant differences between mean values were estimated by using Student's $t$-test. A P value smaller than 0.05 was considered statistically sig-

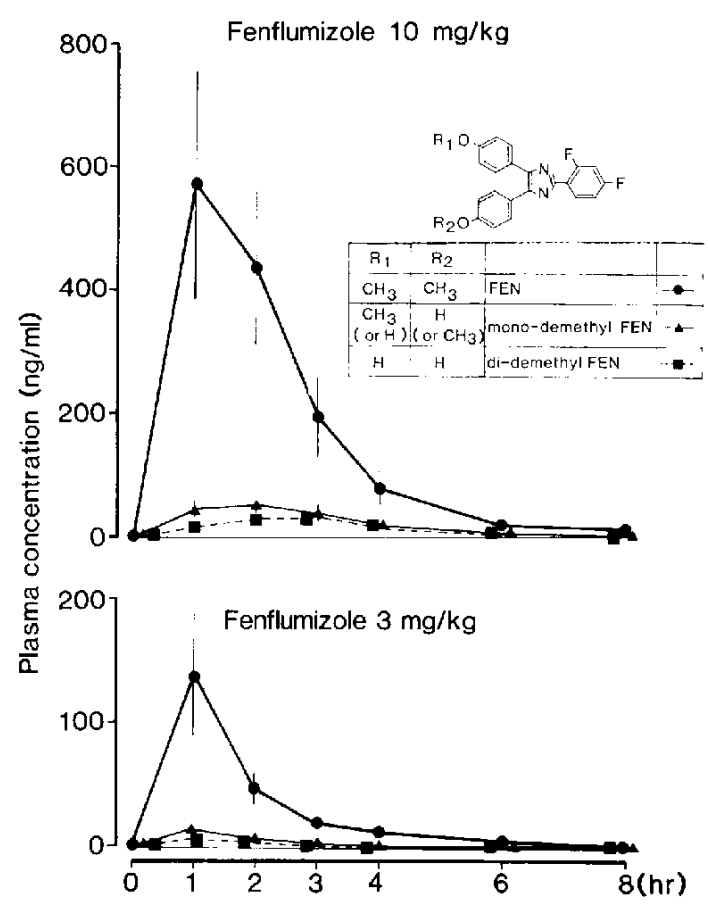

Fig. 1. The mean plasma concentration profile of fenflumizole (FEN) and the two metabolites in dogs given orally 3 and $10 \mathrm{mg} / \mathrm{kg}$ fenflumizole. The vertical bars represent S.E. Each point shows the mean of 5 observations on 5 preparations.

nificant.

Figure 1 shows the mean plasma concentration-time curves of fenflumizole and its metabolites (demethylation products) after oral dosing of 3 or $10 \mathrm{mg} / \mathrm{kg}$ fenflumizole. The plasma levels of fenflumizole and the two metabolites attained to the peak level 1-2 hr after oral dosing of fenflumizole, reaching near the predose levels $8 \mathrm{hr}$ after the dosing. The maximum plasma concentrations $\left(C_{m a x}\right)$ of fenflumizole and the metabolites were as follows: fenflumizole, $144.1 \pm 47.1$ and $700.5 \pm 140.3 \mathrm{ng} / \mathrm{ml}$; the mono-demethyl form, $14.8 \pm 3.9$ and $67.6 \pm 12.2 \mathrm{ng} / \mathrm{ml}$; and the di-demethyl form, $9.1 \pm 1.8$ and $39.2 \pm 13.7$ $\mathrm{ng} / \mathrm{ml}$ for 3 and $10 \mathrm{mg} / \mathrm{kg}$ dosing of fenflumizole, respectively (each $n=5$ ).

The effects of fenflumizole were examined on collagen- and ADP-induced platelet aggregations ex vivo, at different time points, before and 1,2,3, 4, 6 and $8 \mathrm{hr}$ after fenflumizole administration. Fenflumizole given orally in a dose of $10 \mathrm{mg} / \mathrm{kg}$ significantly 


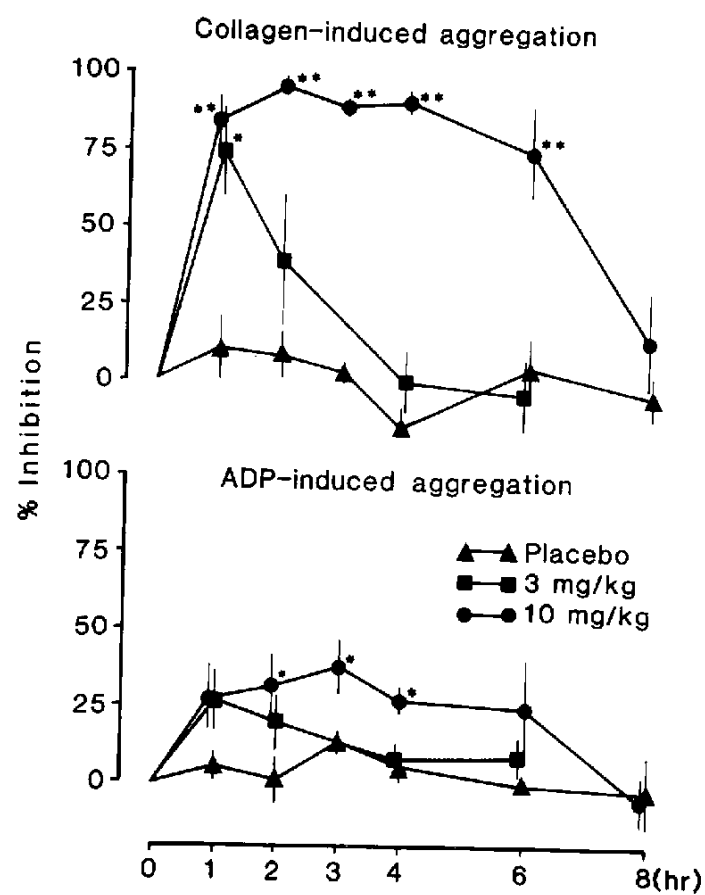

Fig. 2. Time course of the effects of fenflumizole given orally on collagen- and ADP-induced platelet aggregations ex vivo in dogs. The vertical bars represent S.E. Each point shows the mean of 5 observations on 5 preparations. ${ }^{*} P<0.05 .{ }^{*} P<0.01$ compared to the corresponding values obtained from the placebo group.

inhibited both of collagen-and ADP-induced aggregations, although the effect on ADPinduced aggregation was less potent, compared with that on the collagen-induced one (Fig. 2). The inhibitory effects on the aggregations lasted over $4 \mathrm{hr}$. At a dose of 3 $\mathrm{mg} / \mathrm{kg}$, fenflumizole had a significant inhibitory effect, at $1 \mathrm{hr}$ after the dosing, only on collagen-induced aggregation.

In in vitro studies, fenflumizole produced a concentration-dependent inhibition of collagen-induced platelet aggregation in the range of $3 \times 10^{-8}$ to $3 \times 10^{-7} \mathrm{M}$. A metabolite of fenflumizole. the mono-demethyl form, in concentrations of $3 \times 10^{-7}$ to $3 \times 10^{-6} \mathrm{M}$, also effectively inhibited the aggregation. The $50 \%$ effective concentrations (EC50) of fenflumizole and the mono-demethyl form for inhibiting the aggregation were $7.1 \times 10^{-8}$ and $9.2 \times 10^{-7} \mathrm{M}$, respectively. The potency of fenflumizole in inhibiting the aggregation was approximately 13 times higher than that of the mono-demethyl form. Even in a considerably high concentration $\left(10^{-6} \mathrm{M}\right)$. fenflumizole hardly inhibited ADP-induced aggregation, but the mono-demethyl form, unlike fenflumizole, was effective in inhibiting the aggregation, although its potency was relatively weak $\left(10^{-6} \mathrm{M}, 24.8 \pm 4.2 \%, n=5\right)$. The di-demethyl form of fenflumizole, even in high concentrations of $10^{-6}$ to $3 \times 10^{-6} \mathrm{M}$. scarcely had inhibitory effects on either collagen- or ADP-induced aggregation.

The present results demonstrated that fenflumizole given orally to the dog effectively inhibited collagen- and ADP-induced platelet aggregations. Grande et al. (6) claimed that the threshold concentrations for arachidonate- and collagen-induced aggregations ex vivo were significantly increased during treatment of healthy human volunteers with oral fenflumizole, first with $50 \mathrm{mg}$ b.i.d. for 4 or 5 days and then with $200 \mathrm{mg} /$ day for 5 days, but no significant changes were observed in ADP-induced aggregation. However, recent investigations by Grauholt et al. (personal communication by A. Grauholt, P. Grande, J. Wadt and K. Koch. University of Copenhagen and Dumex Ltd., 1985) revealed that in patients with unstable angina pectoris, fenflumizole given orally effectively inhibited ex vivo the platelet aggregations induced by ADP as well as by arachidonate and collagen. Thus, some difference was observed in the inhibitory effect of fenflumizole on ADPinduced platelet aggregation between healthy human volunteers and patients with ischemic heart disease.

According to our previous $(4,5)$ and present studies, fenflumizole was effective in inhibiting arachidonate- and collageninduced aggregations in vitro. While it did not prevent ADP-induced platelet aggregation. Thus, fenflumizole seems to have no inhibitory effect on ADP-induced platelet aggregation. It should be noted, however. that fenflumizole given orally was converted mainly to the two demethylation products, the mono- and di-demethyl forms of fenflumizole, commoniy in rats (4), dogs and humans (9), and that the monodemethyl form was effective in inhibiting ADP-induced aggregation in vitro, even 
though its inhibitory effect appeared relatively weak.

It has been generally known that platelet hyperresponsiveness occurs in patients with ischemic heart disease, probably contributing to the cause of vasospasm, anginal pain and eventually coronary vascular thrombosis (10). Actually. Frishman et al. $(11,12)$ evidenced that patients with angina pectoris demonstrate increased platelet sensitivity to aggregating concentrations of ADP and epinephrine when compared to the normal subjects exposed to the same concentrations of these agents. Fenflumizole may elicit more easily the antiplatelet effects against various aggregating agents in patients with ischemic heart disease than in healthy human volunteers.

In conclusion, the present result indicates that fenflumizole may be a candidate for anti-platelet therapy; and in addition, some active metabolites involving the monodemethyl form formed in the process of a biotransformation of fenflumizole seems to in part contribute to the antiaggregatory effect of fenflumizole. Further studies are needed to evaluate the anti-platelet activity, particularly in patients with ischemic heart disease and in those receiving chronic doses of fenflumizole.

\section{References}

1 Corell, T. and Hasselmann, G.: Pharmacodynamics and toxicology of fenflumizole, a new non-steroidal anti-inflammatory imidazole derivative. Acta Pharmacol. Toxicol. 53, 288-296 (1983)

2 Corell, T., Hasselmann, G., Splawinski, J. and Wojtazek, B.: Fenflumizole: Interactions with the arachidonic acid cascade. Acta Pharmacol. Toxicol. 53, 297-303 (1983)

3 Flower, R.J., Moncada, S. and Vane J.R.: Analgesic-antipyretics and anti-inflammatory agents: Drugs employed in the treatment of gout. In The Pharmacological Basis of Therapeutics. Edited by Gilman, A.G., Goodman, L.S., Rall, T.W. and Murad, F., p. 674-715, MacMillan Publishing Co.. New York (1985)

4 Nabata, H., Uchino, M., Okazaki, A., Yamazaki, T. and Sakai, K.: Antithrombotic and ulcerogenic effects of fenflumizole, a new anti-inflammatory imidazole derivative, in rats. Japan. J. Pharmacol. 44, 93-96 (1987)

5 Aono, J., Nabata, H. and Sakai, K.: Effects of a new anti-inflammatory imidazole derivative, fenflumizole, on platelet aggregation in the rabbit. Japan. J. Pharmacol. 42, 575-578 (1986)

6 Grande, P., Wadt, J. and Corell, T.: Influence of fenflumizole on platelet aggregation in man. Eur. J. Clin. Pharmacol. 27. 169-172 (1984)

7 Vinge, E., Corell, T. and Andersson, K.E.: Effects of fenflumizole on aggregation ex vivo of human platelets and formation of thromboxane $B_{2}$ and 6-keto-prostaglandin $F_{1 x}$. Eur. J. Clin. Pharmacol. 26, 711-717 (1984)

8 Midskov, C.: Reversed-phase chromatography of fenflumizole, a new potential anti-inflammatory agent and its application in pharmacokinetic studies in rat, dog and man. J. Chromatogr. 278, 109-115 (1983)

9 Midskov, C., Vinge, E. and Andersson, K.E.: On the pharmacokinetics of fenflumizole, a novel anti-inflammatory agent, after single oral administration to healthy subjects. Acta Pharmacol. Toxicol. 54, 408-413 (1984)

10 Weiss, H.J.: Platelets and ischemic heart disease. N. Engl. J. Med. 302, 225-226 (1980)

11 Frishman, W.H., Weksler, B., Christodoulou, J.P., Smithen, C. and Killip, T.: Reversal of abnormal platelet aggregability and change in exercise tolerance in patients with angina pectoris following oral propranolol. Circulation 50, 887-896 (1974)

12 Frishman, W.H., Christodoulou, J.P., Weksler, B., Smithen, C., Killip, T. and Scheidt, S.: Abrupt propranolol withdrawal in angina pectoris: Effects on platelet aggregation and exercise tolerance. Am. Heart J. 95, 169-179 (1978) 